\title{
Hypernatraemia in cerebral disorders
}

\author{
W. H. TAYLOR \\ From the Department of Chemical Pathology, United Liverpool Hospitals, \\ Ashton Street, Liverpool
}

SYNOPSIS Six patients are described in whom cerebral damage was associated with raised plasma sodium and chloride concentrations and with extremely low urinary outputs of sodium and chloride. The patients were not clinically dehydrated and direct determinations showed that the blood and plasma volumes, the endogenous creatinine clearance, and the urinary output of antidiuretic hormone were normal. For these and other reasons it is concluded that the metabolic picture results not from diminished circulatory volume, water deficiency, sodium deficiency, undetected diabetes insipidus or osmotic diuresis, but from the cerebral damage itself.

In these and other cited cases, the cerebral damage was localized chiefly in the frontal lobes, hypothalamus or lower brain-stem, thus suggesting a descending pathway, the relationship of which to the pineal area controlling aldosterone secretion requires clarification.

Allott (1939) first reported the occurrence of hypernatraemia and hyperchloraemia, associated with an abnormally low urinary excretion of sodium and chloride, in patients suffering from cerebral disease in whom there was no renal disease, and Higgins, Lewin, O'Brien, and Taylor $(1951,1954)$ described a total of 14 patients in coma after severe head injury in whom the same features were found. Cooper and MacCarty (1951) also described this syndrome in three patients suffering from different intracranial disorders. Subsequently, there have been reports of essentially similar cases (Persson, 1953; Anthonisen, Hilden, and Thomsen, 1954; Elliot, 1955; Allott, 1957; Petit-Dutaillis and BernardWeil, 1958). These authors have, in general, taken the view that the hypernatraemia that they have observed could not be adequately explained without postulating a direct and primary connexion, other than diabetes insipidus, between the cerebral disorder and the metabolic effect.

Hypernatraemia associated with cerebral lesions has been recorded by Sweet, Cotzias, Seed, and Yakovlev (1948), by Natelson and Alexander (1955), and by Schoolman, Dubin, and Hoffman (1955) but unfortunately no records of urine electrolyte excretion are quoted. Sweet et al. and Natelson and Alexander also subscribed to the view that cerebral damage and hypernatraemia are directly connected.

Received for publication 13 October 1961.
Cases of hypernatraemia and hyperchloraemia associated with cerebral damage have also been described in which the metabolic changes clearly result (a) from water deficiency, caused by inadequate intake together with increased losses from sweating, hyperpnoea, or osmotic diuresis (Welt, Seldin, Nelson, German, and Peters, 1952; Ullmann, 1953; Higgins et al., 1954; Gordon and Goldner, 1957); (b) from diabetes insipidus when the patient is unconscious or has an associated defect of the thirst mechanism (Peters, 1948; Welt et al., 1952; Engstrom and Liebman, 1953); (c) from feeding high-protein and high salt-containing synthetic fluid diets to unconscious subjects (Welt et al., 1952; Engel and Jaeger, 1954) so that the osmotic load to be excreted exceeds the capacity of the kidneys and causes retention of urea and sodium. The fact that these three alternative causes of hypernatraemia and hyperchloraemia are known to occur has caused doubt to be thrown on the original concept of encephalogenic hypernatraemia (Wrong, 1957; Fourman and Leeson, 1958).

Hypernatraemia and hyperchloraemia, associated with hyponatruria and hypochloruria, have also been described when there is renal disease associated with cerebral disease (Luetscher and Blackman, 1943; Goodale and Kinney, 1949), when there is severe gastro-intestinal haemorrhage (Borst, 1938), in diabetic coma (Fullerton, Lyall, and Davidson, 1932; McCance and Lawrence, 1935; McCance and 
Widdowson, 1939; Taylor, 1954), and after surgical operation (Taylor, 1951; Zimmermann and Freier, 1952). Borst $(1938,1951)$ has suggested that after haemorrhage hypernatraemia with hyponatruria is a response to an inadequate circulatory volume, even though the volume of extracellular fluid be not itself diminished, and considers that encephalogenic hypernatraemia can also be explained in this way. At the opposite extreme from water deficiency Black (1952) has attributed the findings of Borst (1938) and Allott (1939) to sodium deficiency.

Observations are now presented on six further patients in whom hypernatraemia was associated with cerebral disease, in an attempt to clarify the pathogenesis of this syndrome.

\section{PATIENTS AND METHODS}

Except where stated otherwise, the patients were unconscious from head injury and were maintained on the régime described by Higgins et al. (1954). Feeding by pernasal intragastric tube began after 12 hours and ensured a fluid intake of at least $1,700 \mathrm{ml}$. in the succeeding 24 hours, in addition to such intravenous blood or plasma as was judged necessary. Thereafter a daily fluid intake of at least $2,850 \mathrm{ml}$. was maintained unless dehydration was deliberately undertaken to reduce the pressure of the cerebrospinal fluid. The régime of milk, water, and glucose provided $54 \mathrm{~g}$. protein and $37 \mathrm{mEq}$. of sodium daily and an osmolar load for the kidneys of about $550 \mathrm{~m} .0$ smol.

Blood and plasma volumes were measured by dye dilution using the technique described by Allington and Taylor (1955). Urinary aldosterone was estimated by Dr. R. V. Brooks of St. Thomas's Hospital, London. Antidiuretic hormone was assayed by Dr. R. R. Chaudhary, both by its effect upon the blood pressure of the pithed rat and upon the diuresis of the water-hydrated rat; the hormone was first extracted from urine by the method of Noble, Rinderknecht, and Williams (1939).

The upper limit of normal of plasma sodium is taken as $152 \mathrm{mEq}$./l. and of chloride as $106 \mathrm{mEq}$./litre.

\section{CASE REPORTS}

CASE 1 A 19-year-old motor cyclist was admitted in coma with a right spastic hemiplegia, having suffered a laceration in the left parietal region and fractures of the left clavicle and left forearm. The skull was not fractured. His blood pressure was $190 / 100 \mathrm{~mm}$. Hg. On the next day there was an episode of sweating and his rectal temperature at one time reached $102^{\circ} \mathrm{F}$. Coma deepened during the next 12 hours and a lumbar puncture revealed that the cerebrospinal fluid pressure was over $300 \mathrm{~mm} \cdot \mathrm{H}_{2} \mathrm{O}$. At operation a left subdural haematoma was evacuated. He slowly recovered consciousness during the next 21 days.

At no period did he show any clinical signs of dehydration, nor did his systolic blood pressure fall below $120 \mathrm{~mm}$. Hg. After the operation on day 1 , the fever settled and there was no hyperpnoea. The biochemical data are shown in Table $\mathrm{I}$.

On the fifth day his urinary chloride output fell and chloride was absent from the urine on the sixth day. His plasma chloride and sodium then rose to maximal and abnormal levels on the eighth day. During this day the kidneys began to excrete chloride again and the plasma sodium and chloride concentrations returned to normal. The blood urea rose no more than would be expected in a patient who had suffered two fractures, the urine was never fully concentrated, and the haematocrit levels indicated not haemoconcentration but haemodilution. This, together with the normal blood volume reported below, supports the clinical evidence that there was no dehydration.

CASE 2 A man, aged 56 years, had a left parietal subdural abscess, but despite neurosurgical operation and antibiotic therapy, became progressively comatose and died three weeks after admission. There was intermittent mild fever up to $100^{\circ} \mathrm{F}$. The lowest systolic blood pressure recorded at any time was $98 / 75 \mathrm{~mm} . \mathrm{Hg}$.

There was no clinical evidence of dehydration, but from the thirteenth to the nineteenth days inclusive the patient was given an increased fluid intake in an attempt to increase the output of urine and thus that of urea. The daily oral intake during this period averaged $2,300 \mathrm{ml}$. and the intravenous intake $1,450 \mathrm{ml}$., mainly of $5 \%$ glucose. On the eighteenth day pitting oedema of the skin was noted for the first time and was present at death. Post-mortem examination revealed that the terminal cause of death was pulmonary embolism and that the kidneys showed very mild hypertensive changes. Biochemical data are given in Table I.

This patient's urinary chloride concentration fell on the eighteenth day and thereafter the urine was chloride-free. Afterwards the plasma sodium and chloride rose to abnormal levels, which were highest on the day of death. Thus hypernatraemia developed despite a good urinary output and, as in Case 1, followed the onset of hypochloruria. The increased intake of water resulted not in an increased output of sodium and chloride, but in oedema, and did not prevent the development of hypernatraemia.

CASE 3 A man, aged 22 years, was admitted in coma, one and a half hours after a road accident, with a right hemiparesis, having suffered an extensive, depressed, comminuted fracture of the skull in the left frontalzygomatic region involving the whole of the orbital roof and the left frontal sinus. At operation a few hours later, the brain along the orbital roof was seen to be extensively damaged. The patient slowly recovered consciousness and spoke his first words on the fifteenth day. His blood pressure on admission was $200 / 90 \mathrm{~mm}$. Hg, fluctuated up to $180 \mathrm{~mm} . \mathrm{Hg}$ until day 5 and then settled at $130 / 90 \mathrm{~mm}$. Hg. His temperature rose to $101^{\circ} \mathrm{F}$. on day 3 , fell to $99^{\circ} \mathrm{F}$. 
TABLE I

METABOLIC DATA IN SIX PATIENTS WITH ENCEPHALOGENIC HYPERNATRAEMIA

\begin{tabular}{|c|c|c|c|c|c|c|c|c|c|c|c|c|c|c|c|}
\hline \multirow{2}{*}{$\begin{array}{l}\text { Days } \\
\text { After } \\
\text { Admis- } \\
\text { sion }\end{array}$} & \multicolumn{6}{|l|}{ Plasma } & \multirow{2}{*}{$\begin{array}{l}H b \\
(\%)\end{array}$} & \multirow{2}{*}{$\begin{array}{l}\text { Haema- } \\
\text { tocrit } \\
(\%)\end{array}$} & \multirow{2}{*}{$\begin{array}{l}\text { Fluid } \\
\text { Intake } \\
(\text { ml. })\end{array}$} & \multirow{2}{*}{$\begin{array}{l}\text { Urinary } \\
\text { Volume } \\
(\mathrm{ml} .)\end{array}$} & \multirow{2}{*}{$\begin{array}{l}\text { Gastric } \\
\text { Aspirate } \\
(\mathrm{ml} .)\end{array}$} & \multicolumn{4}{|l|}{ Urine } \\
\hline & $\begin{array}{l}\text { Urea } \\
(\mathrm{mg.l} \\
100 \mathrm{ml} .)\end{array}$ & $\begin{array}{l}\mathrm{Na}^{+} \\
(m E q . / l .)\end{array}$ & $\begin{array}{l}C l^{1} \\
(m E q . / l .)\end{array}$ & $\begin{array}{l}K^{+} \\
(m E q . / l .)\end{array}$ & $\begin{array}{l}\mathrm{HCO}_{3}{ }^{1} \\
(\mathrm{mEq} . / l .)\end{array}$ & $\begin{array}{l}\text { Protein } \\
(\mathrm{g} . / 100 \\
\mathrm{ml} .)\end{array}$ & & & & & & $\begin{array}{l}\text { Urea } \\
(\mathrm{g} . / 100 \\
\mathrm{ml} .)\end{array}$ & $\begin{array}{l}\mathrm{Na}^{+} \\
(\mathrm{mEq} \cdot / l .)\end{array}$ & $\begin{array}{l}C l^{1} \\
(m F a . \mid l .)\end{array}$ & S.G. \\
\hline
\end{tabular}

\begin{tabular}{|c|c|c|c|c|c|c|c|c|c|c|}
\hline 1 & 36 & & 98 & & & & 42 & & & \\
\hline 3 & 48 & & 97 & & & 6.0 & 38 & $3 \cdot 2$ & 89 & 1.020 \\
\hline 5 & 62 & & 100 & & & 6.4 & 36 & 3.6 & 6 & 1.010 \\
\hline 6 & 64 & 150 & 105 & $4 \cdot 6$ & & & & 3.7 & 0 & 1.015 \\
\hline 8 & 60 & 154 & 111 & & & 6.6 & 37 & $3 \cdot 2$ & 26 & 1.015 \\
\hline 9 & 58 & 144 & 107 & $4 \cdot 8$ & 18 & & & $3 \cdot 1$ & 34 & 1.015 \\
\hline 11 & 23 & & 103 & & & 6.7 & 39 & & & \\
\hline 13 & 36 & 134 & 101 & & & & & $2 \cdot 7$ & 25 & 1.014 \\
\hline
\end{tabular}

$\begin{array}{rrrrr}33 & 128 & 99 & & \\ 43 & 139 & 99 & 5 \cdot 3 & \\ 94 & 130 & 96 & & \\ 180 & & & & \\ 140 & 129 & 101 & 5 \cdot 4 & \\ 224 & & & & \\ 277 & 140 & 102 & 7 \cdot 6 & 22 \\ & & & & \\ 112 & 148 & 113 & & \\ 240 & 153 & 110 & 6.9 & \end{array}$

6.9

$\begin{array}{llll}89 & & & \\ 87 & & & \\ & & & \\ & 3,720 & 1,420 & 2 \cdot 8 \\ 78 & 2,300 & ? & \\ & 2,730 & 430+ & 2 \cdot 6 \\ & 2,300 & ? & 1 \cdot 9 \\ & 6,930 & 4,625 & 2 \cdot 4 \\ & 5,430 & 3,125 & 0 \cdot 8 \\ & 2,870 & 570+ & 2 \cdot 3 \\ & 2,300 & ? & 1 \cdot 1\end{array}$

$\begin{array}{lrrr}27 & & 97 & \\ 54 & 142 & 106 & 4 \cdot 6 \\ 98 & & 109 & \\ 75 & 160 & 115 & 4 \cdot 6 \\ 44 & & 111 & \\ 35 & 145 & 103 & 4 \cdot 6 \\ 48 & 147 & 105 & 5 \cdot 0\end{array}$

$1,280 \quad 43$

$2,610 ?$

$2,485 \quad 740+$

$2,485 \quad 1,250+$

$2,730 \quad 2,160$

$3,410 \quad 1,620+$

$3,125 \quad 1,335$

$3,410 \quad 1,140+$

$2,500 \quad 2,385+$

$\begin{array}{rrrrr}80 & 174 & 107 & 4 \cdot 4 & 32 \\ 80 & 172 & 107 & 4 \cdot 4 & 33 \\ 84 & 179 & 115 & 5 \cdot 1 & 31 \\ 100 & & & & \\ & 181 & 128 & 4 \cdot 1 & 31 \\ 89 & 174 & 124 & 3 \cdot 9 & 37 \\ 90 & & & & \\ 76 & 168 & 124 & 3 \cdot 6 & 31 \\ 70 & 169 & 118 & 3 \cdot 5 & 32 \\ 80 & 155 & 123 & 4 \cdot 1 & 33 \\ 75 & 152 & 111 & 4 \cdot 6 & 29 \\ 70 & & 107 & & 31 \\ 71 & 140 & 105 & 4 \cdot 6 & 27\end{array}$

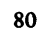

80
92

74


81
71
68
80
69
73


109

120
105
107
106

80
92

74

81

71
68

68
80
69

73

109

$\begin{array}{lllll}120 & & & & \\ 125 & 167 & 117 & 3 \cdot 7 & 20 \cdot 6 \\ 165 & 163 & 118 & 4 \cdot 0 & 22 \cdot 8 \\ 200 & 157 & 118 & 5 \cdot 4 & \\ 255 & 157 & 118 & 6 \cdot 0 & 18 \cdot 1 \\ 400 & 165 & 129 & 6 \cdot 2 & 16 \cdot 2\end{array}$

$\begin{array}{rrrrr}60 & 141 & 113 & 3 \cdot 2 & 10 \\ 60 & 136 & 118 & 3 \cdot 9 & 24 \\ 75 & 144 & 120 & 4 \cdot 4 & 14 \\ 95 & 147 & 114 & 4 \cdot 1 & 25 \\ & 154 & 109 & & \\ 70 & 143 & 99 & 3 \cdot 2 & 33\end{array}$



$1 \cdot 034$

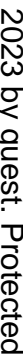

is included $1 \cdot 1 \mathrm{l}$. isotonic sodium chloride solution. 
on day 4, and was thereafter normal. During the period of coma there was no clinical evidence of dehydration and the intake of fluid always exceeded the recorded output. Biochemical data are given in Table I.

Hyperchloraemia developed on the fifth day after admission and was maximal on the sixth day, when a comparable hypernatraemia was also recorded. As in Case 1, the blood urea did not rise to levels higher than one would normally associate with an injury of this severity (Higgins et al., 1954). The blood urea was already declining when hyperchloraemia reached its maximum; had hypernatraemia and hyperchloraemia arisen from water deficiency, the blood urea should have continued to rise. The urinary chloride levels were low, but not so low as is usual in these patients. The daily output of chloride and possibly therefore of sodium, on day 5, was sufficient to account for the small amounts of sodium ( $37 \mathrm{mEq}$.) and chloride ( $45 \mathrm{mEq}$.) in the diet, so that in this patient the increased plasma concentrations of sodium and chloride between days 5 and 6 must have arisen from endogenous sources.

CASE 4 A man, aged 28 years, was transferred from another hospital in semi-coma following an injury to the right temporal region. After removal of a subdural haematoma he made a gradual recovery. There was no hyperpnoea and no sustained pyrexia, although readings in the range $99-100^{\circ} \mathrm{F}$. were occasionally obtained. There was no clinical evidence of dehydration. From days 1 to 7 he was given mist. sod. citr. ( $31 \mathrm{mEq}$./day) in mistake for mist. pot. citr. The biochemical data are shown in Table I.

Hypernatraemia and hyperchloraemia were present on admission. The chloride content of the urine was low. Normal plasma levels were not attained until the ability to excrete sodium and chloride in the urine returned. The accidentally increased sodium intake undoubtedly accentuated the hypernatraemia.

CASE 5 A man, aged 53 years, was admitted to hospital complaining of tiredness and abdominal pain and was found to have chronic lymphatic leukaemia. His urine was examined and found to be normal. Three months later he was re-admitted, having lost consciousness two days previously for 15 minutes and having noticed increasing thirst, polyuria, and nocturia over the previous eight weeks. He was able to give a good history and the notes describe him as an 'affable fellow'. Examination of the central nervous system revealed no abnormality. He was given a normal ward diet with free access to fluids and his body temperature fluctuated in typical leukaemic fashion between $98.0^{\circ} \mathrm{F}$. and $102.6^{\circ} \mathrm{F}$. Over a period of 72 hours he became drowsy and irritable and showed excessive reaction to stimuli. Urine examination at this point revealed a moderate glycosuria but the ferric chloride test for ketone bodies was negative. On the next day he was found to have a severe hyperglycaemia ( 880 mg. $/ 100 \mathrm{ml}$.) and, as shown in Table I, hypernatraemia and hyperchloraemia. Clinically, there were signs of mild dehydration but it should be noted that the blood urea level, which was raised on admission, had not altered significantly. The plasma bicarbonate was normal. The patient was treated with insulin, and given a high intravenous and oral fluid intake over the next $\mathbf{4 8}$ hours. The hyperglycaemia proved difficult to control and the patient's condition deteriorated. Despite the high fluid intake and good urinary output, the hypernatraemia and hyperchloraemia persisted and the blood urea and serum potassiun levels rose. The urinary urea concentration was abnormally low, indicating renal failure.

Necropsy showed the characteristic hepatosplenomegaly of chronic lymphatic leukaemia, oedema of the lower lobes of both lungs with bronchopneumonia on the left side, and a recent haemorrhage into the hypothalamus tracking into the left lateral ventricle. Older clot, with softening of the hypothalamus and some fibrous thickenings of the meninges, was present near the optic chiasma (Fig. 1). The kidneys had a smooth surface and the capsule stripped easily. There was no necrosis of the renal medulla. Histologically, changes similar to those of the pre-necrotic stage of acute renal failure (Brun, 1954; Taylor and Reid, 1958) were observed.

This patient showed three metabolic changes that

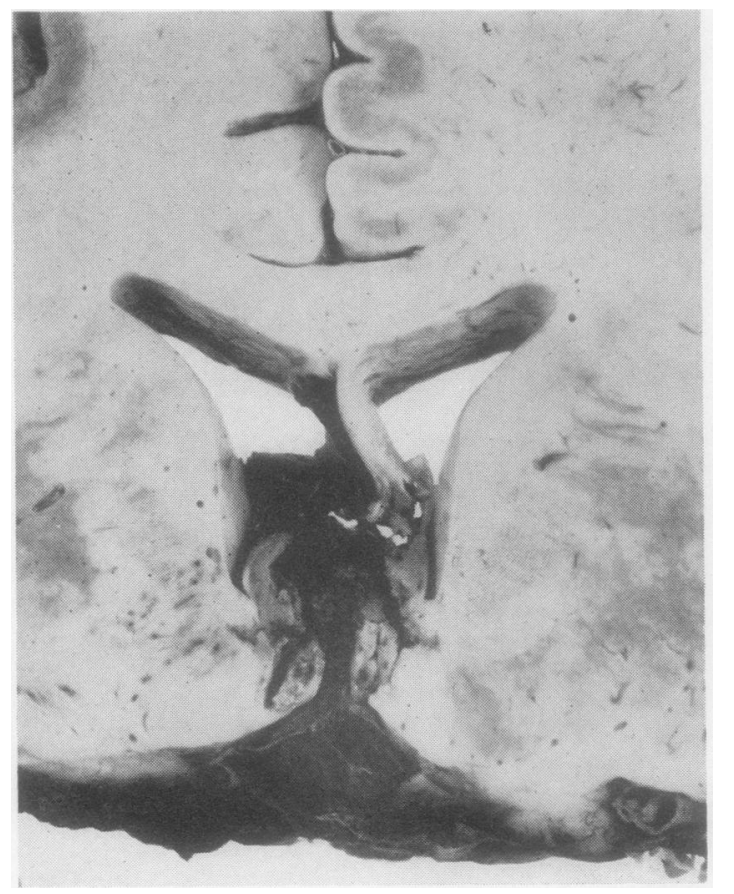

FIG. 1. Section of brain of Case 5 showing haemorrhage into hypothalan:us. 
have been associated with brain damage: hyperglycaemia, hypernatraemia, and acute renal failure (Higgins et al., 1954, Taylor, 1957). Unfortunately, urinary sodium and chloride were not determined, so that the presence of hyponatruria and hypochloruria can only be inferred from the persistence of hypernatraemia in the presence of an adequate urinary output, and the knowledge that the sodium and chloride intake was not greater than $50 \mathrm{mEq}$./ day, except on day 3 . The great interest attaching to this patient is the precise localization in the hypothalamus of the responsible cerebral lesion. Hyperglycaemia and polyuria probably date from the time of the earlier haemorrhage.

CASE 6 A woman, aged 77 years, was admitted with haematemesis. Her blood pressure was $100 / 60 \mathrm{~mm} . \mathrm{Hg}$ and soon fell to 45/?. Despite energetic transfusion, the systolic pressure remained around $75 \mathrm{~mm}$. Hg. Bleeding continued, and on the next day an emergency gastrectomy was carried out. The stomach contained 3 pints of blood and in the posterior wall was a large ulcer, deeply embedded in the pancreas, with three bleeding vessels. After operation she remained comatose and developed auricular fibrillation although the blood pressure returned gradually to $190 / 100 \mathrm{~mm} . \mathrm{Hg}$. On the third post-operative day muscular tremor and twitching developed and her body temperature rose to $104^{\circ} \mathrm{F}$. She sometimes responded slowly to questioning, but could not move her limbs, which were held in the extensor position and showed increased tone. The right plantar response was thought to be extensor, but the reflexes were otherwise normal. There was moderate hyperpnoea. Over the next two days she became more alert and was able to swallow, but otherwise the clinical picture was relatively unchanged. It was then decided to reduce her body temperature to $94^{\circ}-97^{\circ} \mathrm{F}$. During this period the electric fans stopped because of an electrical failure and her temperature rose in two hours to $101.8^{\circ} \mathrm{F}$. This marked instability of temperature regulation persisted until her death three months later. Metabolic data are given in Table I. After the blood volume and blood pressure had been restored to normal, there was no clinical evidence of dehydration. On days 6 and 7 mild oedema of the ankles, sacrum, and wrists was present.
Hyperchloraemia developed post-operatively in the presence of a low plasma bicarbonate level and a normal plasma sodium concentration and was probably the result of respiratory alkalosis arising from the excessive hyperpnoea. The hyperchloraemia persisted, however, and hypernatraemia followed, accompanied by low urinary sodium and chloride concentrations. The restoration of normal plasma levels coincided with the return of urinary excretion of these ions. The cerebral injury in this patient was probably anoxic in origin; the temperature disturbances suggest a localization in the hypothalamus or lower brain-stem; the hyperpnoea and extended limbs suggest a localization in the lower brain-stem.

\section{SPECIAL INVESTIGATIONS}

BLOOD AND PLASMA volumes These determinations were made on the day of maximal hypernatraemia in Cases 1 and 2, and again in Case 1 when the patient had recovered (Table II). The volumes in each instance were within the normal range.

RENAL FUNCTION TESTS Determinations of endogenous creatinine clearance and of the percentage chloride reabsorption were made on Case 3 on days 6 and 7, which were those of maximal hypernatraemia. The bladder was catheterized and each determination carried out over a period of two hours. The values were as follows:

\begin{tabular}{lcc} 
Day & $\begin{array}{l}\text { Endogenous Creatinine } \\
\text { Clearance }(\text { ml./min.) }\end{array}$ & $\begin{array}{l}\text { Tubular Chloride } \\
\text { Reabsorption (\%) }\end{array}$ \\
\hline 6 & $121 \cdot 5$ & $99 \cdot 8$ \\
7 & 110 & $99 \cdot 8$
\end{tabular}

TESTS OF ENDOCRINE FUNCTION Determinations were made upon 24-hour samples of urine in patients 3 and 4. The ketosteroid values were within the normal range. The aldosterone values, which were uncorrected for losses during analysis, were high normals. The antidiuretic hormone values are not easy to interpret because of the tenfold discrepancy between the two methods but would appear to fall within the normal range given by Stein, Jinks, and Mirsky (1952) as $6 \cdot 3$ to $24 \cdot 7 \mathrm{mU} /$ day.

TABLE II

CIRCULATORY VOLUMES AND URINARY EXCRETION OF HORMONES AT THE HEIGHT OF HYPERNATRAEMIA

\begin{tabular}{|c|c|c|c|c|c|c|c|c|}
\hline \multirow[t]{2}{*}{ Case } & \multicolumn{2}{|c|}{ Plasma Volume } & \multicolumn{2}{|c|}{ Blood Volume } & \multicolumn{2}{|c|}{$\begin{array}{l}\text { Antidiuretic Hormone } \\
\text { (mUnits } / 24 \text { hours) }\end{array}$} & \multirow{2}{*}{$\begin{array}{l}\text { 17-Ketosteroids } \\
\text { (mg./24 hours) }\end{array}$} & \multirow{2}{*}{$\begin{array}{l}\text { Aldosterone } \\
\text { ( } \mu . g . / 24 \text { hours })\end{array}$} \\
\hline & $(m l)$. & $(\mathrm{ml} . / \mathrm{kg})$. & $(m l)$. & $(\mathrm{ml} . / \mathrm{kg})$. & $\begin{array}{l}\text { Pithed Rat } \\
\text { B.P. }\end{array}$ & $\begin{array}{l}\text { Water- } \\
\text { hydrated Rat }\end{array}$ & & \\
\hline $\begin{array}{l}1 \text {, on day } 8 \\
1 \text {, recovered } \\
2 \text {, on day } 21 \\
\text { Normal range } \\
3 \text {, on day } 6 \\
4 \text {, on day } 8 \\
4 \text {, on day } 9\end{array}$ & $\begin{array}{c}2,250 \\
2,340 \\
2,405 \\
-\end{array}$ & $\begin{array}{l}37 \cdot 5 \\
39 \cdot 0 \\
40 \cdot 1 \\
31-54\end{array}$ & $\begin{array}{c}3,590 \\
3,800 \\
3,680 \\
-\end{array}$ & $\begin{array}{l}59 \cdot 8 \\
63 \cdot 3 \\
61 \cdot 3 \\
51 \cdot 86\end{array}$ & $\begin{array}{l}7.96 \\
6.00 \\
-\end{array}$ & $\begin{array}{l}- \\
-\end{array}$ & $\begin{array}{r}\overline{7 \cdot 4} \\
11 \cdot 2\end{array}$ & $\begin{array}{r}10 \cdot 5 \\
8 \cdot 1 \\
-\end{array}$ \\
\hline
\end{tabular}




\section{DISCUSSION}

Renal disease, and the feeding of high-protein, highsalt diets, can immediately be eliminated as principal causes of hypernatraemia in these patients. There then remain five hypotheses: 1 That hypernatraemia is brought about by, and is a response to, a diminished circulatory volume; 2 , that it is a manifestation of sodium deficiency; 3 , that it is a manifestation of water deficiency arising from undetected diabetes insipidus; 4 , that it is a manifestation of water deficiency arising from inadequate intake coupled with excessive losses from sweating or osmotic diuresis; and 5, that it is a primary manifestation of the cerebral injury.

The special investigations described above were designed to help in the differentiation between these hypotheses.

DIMINISHED CIRCULATORY VOLUME This hypothesis (Borst, 1938) requires at least that there should be haemorrhage or some other cause of a diminished blood volume and that there should be a fall of blood pressure. In most of the patients described by Higgins et al. $(1951,1954)$ and by Allott (1957), and in five of the six patients described above there was no significant haemorrhage, no significant loss of fluid into damaged tissues, no recorded fall of blood pressure, and no other feature, such as tachycardia, suggesting an inadequate circulatory volume. Furthermore, the circulatory plasma and blood volumes were determined in two patients of the present series at the height of hypernatraemia, and were found to be well within the normal limits. In one of these patients the plasma and blood volumes were determined again after recovery and had not increased significantly. Thus hypernatraemia with hyponatruria can occur when there is cerebral damage without there being any relative or absolute deficiency of circulatory volume, although it may well be that after severe haemorrhage these metabolic changes constitute a physiological response designed to preserve the extracellular volume.

UNDETECTED DIABETES INSIPIDUS In the comatose hypernatraemic patients of Peters (1948) and of Engstrom and Leibman (1953) the daily urinary volumes were high and the urinary specific gravity low, so that a diagnosis of diabetes insipidus could quite properly be made. In contrast to these findings the patients described above and those of Higgins et al. $(1951,1954)$ had urinary volumes that were within the normal range and the specific gravity of their urines was higher. These observations in themselves exclude diabetes insipidus but any remaining doubt is removed by the present observation that normal amounts of antidiuretic hormone were excreted in the urine of two patients at the height of hypernatraemia. A further point of difference between our patients and those with undetected diabetes insipidus arises from the urinary sodium and chloride excretion. The daily excretion of sodium during hypernatraemia in undetected diabetes insipidus (Engstrom and Liebman, 1953) ranged from 40 to $90 \mathrm{mEq}$. with a concentration of $\triangleq$ 30 to $35 \mathrm{mEq} . / 1$. and that of chloride ranged from 90 to $140 \mathrm{mEq}$. with a concentration of 50 to 60 $\mathrm{mEq}$./litre. These urinary losses are very much higher than those occurring with comparable degrees of hypernatraemia in the patients described above and in those of Higgins et al. $(1951,1954)$ and of Allott $(1939,1957)$ in whom, as Allott has emphasized, the $\dot{\omega}$ excretion of sodium and chloride may be nil.

SODIUM DEFICIENCY This hypothesis (Black, 1952) rests on the assumption that profound hyponatruria and hypochloruria would not occur, whatever the extracellular concentration of these ions, unless there were in fact a deficiency of them in the body. However, our present knowledge of the relationship between total body sodium and chloride and the renal excretion of each ion, in diverse conditions such as congestive cardiac failure, respiratory acidosis, and hyperaldosteronism, makes the validity of such an assumption questionable. The evidence against sodium deficiency is indeed formidable. Thus in Allott's original cases, and in most of those reported subsequently, there was no source of significant extrarenal loss of sodium, nor were dehydration and the other signs and symptoms of sodium depletion present. The occurrence of hypernatraemia and oedema in some of the patients makes a total body sodium deficit highly unlikely. The normal endogenous creatinine clearance in Case 3 would not be compatible with sodium depletion, and in Case 4 the provision of oral sodium failed to prevent hypernatraemia. Indeed it has been emphasized (Higgins et al., 1951, 1954; Allott, 1957) that feeding sodium salts increases the hypernatraemia and makes the clinical condition worse.

WATER DEFICIENCY There is no doubt that the N régime used by Higgins et al. (1954) may, designedly, provide an insufficient water intake during the first 24 hours after injury. Thereafter, as Table I indicates, the fluid intake is sufficient to provide for the needs $\stackrel{\leftrightarrow}{\rightarrow}$ of the patient. For this reason, and because there was 0 no clinical evidence of water deficiency in these and 0 other patients, it is difficult to ascribe hypernatraemia to this cause. There are many other $\frac{\Omega}{\mathbb{D}}$ features which confirm that water deprivation is unlikely to be the major factor in the pathogenesis of cerebral hypernatraemia. 
1 Higgins et al. (1954) used their regimen in a consecutive series of patients with head injury who remained in coma after 12 hours. Some showed hypernatraemia with hyponatruria but the majority, including many with injuries of comparable severity, and comparable degrees of hyperpnoea and fever, failed to do so. This suggests that the cause is something peculiar to the affected patients, for if hypernatraemia were the fault of the régime it should have occurred more frequently.

2 When water deprivation occurred in the series of patients of Higgins et al. (1954) it was easily diagnosed from the history and the typical clinical features, which were often marked when hypernatraemia was either absent or slight. In these patients the urinary chloride and sodium concentrations were high, of the order of 75 to $100 \mathrm{mEq}$. $/ 1$. and the urinary volumes low. These same distinctions also characterized patients with head injury in whom water deprivation was induced therapeutically because of a persistently high cerebrospinal fluid pressure.

3 As Table I shows, hypernatraemia and hyperchloraemia usually arise on the third to seventh days after injury and are preceded by an unusual degree of hyponatruria and hypochloruria. As Cases 1, 4, and 6 illustrate, the return of the plasma sodium and chloride levels to normal is frequently accompanied by a significant increase in the urinary excretion of sodium and chloride. Thus the serum concentrations appear to follow and be secondary to the changes in urinary excretion.

4 In the hypernatraemia of water deprivation, on the other hand, a different pattern occurs. There is usually an early phase in which the urinary concentrations of sodium and chloride are raised in an attempt to maintain the isotonicity of the extracellular fluid (McCance, Young, and Black, 1944; Peters, 1948). Black (1952) writes: 'A low 24-hour urine volume, especially if it be associated with a high specific gravity and high concentration of sodium, urea, and chloride, is a sign that water intake is inadequate.'

Even when excessive urinary loss is the cause of water deficiency, the urinary sodium and chloride concentration remain relatively high, as in the hypernatraemic patient with diabetes insipidus described by Engstrom and Liebman (1953). When water deprivation is combined with a low sodium intake, or with an unduly high urea load, the urinary sodium and chloride concentrations are still higher than those found in cerebral hypernatraemia. As Allott (1957) points out:

'Nadal, Pedersen, and Maddock (1941), by water deprivation in a person on a salt-deficient diet, found urinary chloride values of 35 and $19 \mathrm{mEq}$. per litre; only when gross salt deficiency was produced by intestinal suction in an already salt-deficient patient did the urinary sodium and chloride fall to really low values, and this was associated with very low values of the electrolytes in the serum.

McCance et al. (1944) produced an osmotic diuresis in a dehydrated person by giving urea, $35 \mathrm{~g}$., intravenously; the urinary sodium decreased from 125 to $17 \mathrm{mEq}$. per litre as the urea increased from 2.9 to $4.8 \mathrm{~g}$. per $100 \mathrm{ml}$.; but this amount of urea is very much more than was observed in either of the present patients, and the depression of urinary electrolytes very much less.'

5 If cerebral hypernatraemia were only a matter of water deficiency, an increased fluid intake should restore the metabolic picture to normal. When this is done, however, generalized oedema may result, if the urinary sodium and chloride output is zero (as in Case 2). If small amounts of sodium and chloride are being excreted, the plasma sodium and chloride level may slowly fall because of the increased total output of urine that is induced, and oedema may be avoided. If under these circumstances the sodium intake is increased, the urinary concentration of sodium and chloride is not increased, and hypernatraemia with oedema occurs (Higgins et al., 1954). Natelson and Alexander (1955) and Allott (1957) have observed that the ability to excrete sodium and chloride freely, in the normal homeostatic fashion, may not be restored for several weeks.

6 The occurrence of oedema in two of the present patients at the height of hypernatraemia and hyperchloraemia, and the normal endogenous creatinine clearances of a third, also argue against the existence of a severe water deficit.

PRIMARY ENCEPHALOGENIC HYPERNATRAEMIA The exclusion of the alternative hypotheses focuses attention upon the possibility that the brain damage has itself caused a disturbance of homeostasis in which the sodium balance is so regulated as to maintain, temporarily, a hyperosmotic state. The absence of dehydration and of cardiovascular collapse would be compatible with this hypothesis, as would the existence of the reverse metabolic picture of hyponatraemia with hypernatruria in patients with brain damage (Welt et al., 1952; Higgins et al., 1954). The nature of the brain damage, the renal mechanism causing hyponatruria, the brain-kidney pathway, and the source of the additional sodium and chloride ions involved need closer examination.

CEREBRAL LESION Table III indicates the site of brain damage in those patients whose hypernatraemia 
TABLE III

IDENTIFIED SITES OF BRAIN DAMAGE IN PUBLISHED CASES OF ENCEPHALOGENIC HYPERNATRAEMIA

\begin{tabular}{|c|c|c|c|}
\hline Authors & $\begin{array}{l}\text { Number of } \\
\text { Patients }\end{array}$ & Clinical Lesion & Sites of Localized Brain Damage \\
\hline Allott (1939) & $\begin{array}{l}1 \\
1 \\
1\end{array}$ & $\begin{array}{l}\text { Left hemiparesis } \\
\text { Cerebral haemorrhage } \\
\text { Adenoma, choroid plexus }\end{array}$ & $\begin{array}{l}\text { Right internal capsule degeneration } \\
\text { Aneurysm of left anterior cerebral artery, haemorr- } \\
\text { hage between frontal lobes } \\
\text { Infiltration of tumour into right posterior lobe }\end{array}$ \\
\hline Sweet et al. (1948) & $\begin{array}{l}1 \\
1 \\
1 \\
1\end{array}$ & $\begin{array}{l}\text { Pre-frontal leucotomy } \\
\text { Glioma of third ventricle } \\
\text { Astrocytoma, frontal } \\
\text { Meningioma, near pituitary }\end{array}$ & $\begin{array}{l}\text { Incision anterior to anterior commissure passing } \\
\text { on each side through tip of anterior horn } \\
\text { Removed by transcallosal approach } \\
\text { Right frontal lobectomy } \\
\text { Subtotal removal of meningioma; amputation of } \\
\text { anterior } 3 \mathrm{~cm} \text {. of frontal lobe }\end{array}$ \\
\hline Higgins et al. $(1951,1954)$ & 11 & Head injury & $\begin{array}{l}\text { Orbital surface of frontal lobes in all; pituitary } \\
\text { gland haemorrhage in six of nine }\end{array}$ \\
\hline Cooper and MacCarty (1951) & $\begin{array}{l}1 \\
1 \\
1\end{array}$ & $\begin{array}{l}\text { Pituitary tumour. Bilateral anterior } \\
\text { cerebral arterial occlusion } \\
\text { Pituitary tumour (removed surgically) } \\
\text { Thrombosis left middle cerebral } \\
\text { artery }\end{array}$ & $\begin{array}{l}\text { Infarction of both frontal lobes and of corpus } \\
\text { striatum; subtotal resection of right frontal lobe } \\
\text { Pituitary } \\
\text { Left basal ganglia }\end{array}$ \\
\hline Cooper and Crevier (1952) & $\begin{array}{l}1 \\
1\end{array}$ & $\begin{array}{l}\text { Tumour in third ventricle of brain } \\
\text { Craniopharyngioma }\end{array}$ & $\begin{array}{l}\text { Hypothalamus } \\
\text { Frontal lobes and hypothalamus }\end{array}$ \\
\hline Anthonisen et al. (1954) & 1 & Head injury & $\begin{array}{l}\text { Contusions of under side of right frontal and } \\
\text { temporal lobes and of left frontal lobe, extending } \\
\frac{1}{10} 1 \frac{1}{2} \mathrm{~cm} \text {. into brain substance }\end{array}$ \\
\hline Elliot (1955) & 1 & Multiple sclerosis & Hypothalamic and bulbar lesions, among others \\
\hline Allott (1957) & 2 & Bulbar poliomyelitis & Brain-stem \\
\hline Present series & $\begin{array}{l}1 \\
1 \\
1\end{array}$ & $\begin{array}{l}\text { Head injury } \\
\text { Cerebral haemorrhage } \\
\text { Cerebral anoxia and hyperthermia }\end{array}$ & $\begin{array}{l}\text { Orbital surface of frontal lobes } \\
\text { Haemorrhage into hypothalamus } \\
\text { Brain-stem }\end{array}$ \\
\hline
\end{tabular}

is thought by the authors concerned to be encephalogenic. It shows that damage occurs preponderantly in the frontal lobes, particularly the orbital surface, in the hypothalamic-pituitary region, and in the brain-stem. The present patients also include one (Case 3) with severe damage to the orbital surface of the frontal lobes, one (Case 5) with an unambiguous haemorrhage into the hypothalamus, and another (Case 6) in whom the pathological lesion can be localized clinically to the brain-stem. There is thus a suggestion of a pathway-frontal cortex-hypothalamus-brain-stem-interruption of which can bring forth the hypernatraemic-hyponatruric response.

Disordered sodium balance may be provoked in animals by stimulation or destruction of the hypothalamus or of areas in the brain-stem. Thus unilateral lesions in the floor of the fourth ventricle of rabbits provoked a diuresis with increased excretion of chloride ions (Jungmann and Meyer, 1913); bipolar stimulation of the caudal portion of the floor of the fourth ventricle in dogs resulted in an increased excretion of sodium (Wise, 1956); cerebral hypoxia increased the tubular reabsorption of sodium in the dog (Földi, Korách, and Takács,
1955); unilateral lesions in the hypothalamus of cats caused hyperchloraemia and hypochloruria, with maximal blood levels at three to six hours (Lewy and Gassmann, 1935). In this last experiment the changes were too acute to be attributed to factors such as water deficiency.

No data in animals are available about the relation of sodium balance to the frontal lobes, although a connexion of this area with hyperglycaemia and with renal cortical ischaemia has been suggested (Cort, 1953; Anand and Dua, 1956). Recently Farrell (1959) and his associates have produced evidence that the or pineal body and associated areas of the diencephalon $N$ are concerned with the release of aldosterone. No $\underset{\omega}{N}$ cases of hypernatraemia with hyponatruria have yet been described in association with clinical lesions of this area, although one of Allott's (1939) cases (adenoma of the choroid plexus) and one of Sweet $\stackrel{\oplus}{\oplus}$ et al. (glioma of the third ventricle) may be of 0 significance in this context. So also might be the patient described by Cort (1954), who had hypo- $\mathbb{D}$ natraemia with hypernatruria and a tumour of the posterior thalamus.

The combined clinical and animal observations suggest that the relationship of the orbital surface 8 
of the frontal lobes to the pineal region and of both to the hypothalamus and to the brain-stem should be urgently explored.

RENAL MECHANISM CAUSING HYPONATRURIA The glomerular filtration rate (mannitol clearance) was found to be only $30 \%$ of normal in a patient of Luetscher and Blackman (1943) in whom there was combined cerebral and renal disease. The endogenous creatinine clearance at the height of hypernatraemia in one of Allott's (1957) patients, in whom there was muscle wasting, was $39 \mathrm{ml} . / \mathrm{min}$., but in another it was $160 \mathrm{ml} . / \mathrm{min}$., and in Case 3 of the present series a normal value was also obtained. Whether the glomerular filtration rate be normal or low, it is the very high percentage reabsorption of sodium and chloride which impresses. Thus, so intense were the forces promoting sodium reabsorption in Allott's second patient that a foreign anion, thiosulphate, was almost completely reabsorbed also.

Allott (1957) found a high aldosterone output in one patient, and high-normal excretions occurred in Cases 3 and 4 of the present series, so that this hormone almost certainly plays an important part in causing the hyponatruria. That it is not the only factor is indicated by the observation of August, Nelson, and Thorn (1958) that the intramuscular injection of large doses of aldosterone in normal subjects never reduced the sodium excretion to less than $10 \mathrm{mEq}$./day and did not promote a significant hypernatraemia.

BRAIN-KIDNEY PATHWAY Since section of the splanchnic nerves (Cushny, 1926) and denervation of the kidney (Sartorious and Burlington, 1956) have been shown to influence the excretion of sodium and chloride ions by the kidney, tentative pathways might be

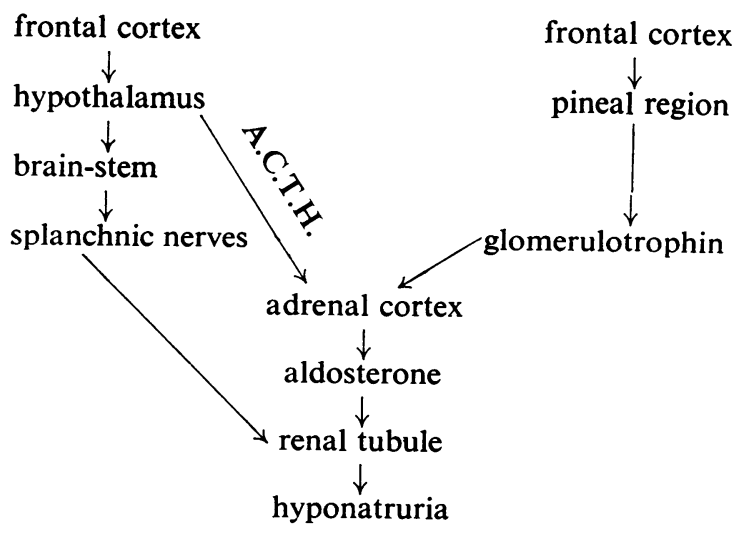

The final steps in both pathways are probably the same as those brought into play when a low circulatory volume and diabetic coma cause hypernatraemia with hyponatruria. In encephalogenic hypernatraemia the response is initiated by cerebral damage, not by hypovolaemia.

SOURCE OF SODIUM AND CHLORIDE IONS When extracellullar sodium and chloride concentrations rise, without significant dehydration, the ions must be supplied from somewhere. The principal source is probably dietary; $37 \mathrm{mEq}$./day in the present patients, in the absence of sodium loss, would give a daily rise of 3 to $4 \mathrm{mEq}$./1., which is approximately what is observed. Borst (1938) noted that in one patient 'the excretion of sodium chloride was still so scanty that the consumption of but a small quantity of milk was sufficient to establish a positive sodium and chloride balance'.

However, as was noted in Case 3, not all increases of extracellular concentration can be explained in this way, and the possibility of transfer between the body compartments must be considered. After head injury, intracellular sodium ions may to some extent become available from damaged cells. Another possible source is the red cells; thus Maizels and McArthur (1930) observed high plasma chloride concentrations, with low erythrocyte concentrations, in infantile diarrhoea.

I wish to thank Mr. J. B. Pennybacker, Mr. W. S. Lewin, Dr. E. T. Baker Bates, and Mr. J. Cosbie Ross to whose wards the patients were admitted; Mr. J. R. P. O'Brien, Dr. T. Black, and Dr. C. St. Hill who have allowed me to quote estimations made in their laboratories; Dr. $\mathbf{R}$. R. Chaudhary and Dr. R. V. Brooks for the estimation, respectively, of antidiuretic hormone and aldosterone, and Dr. J. Watt who carried out the necropsy on Case 5.

\section{REFERENCES}

Allington, M. J., and Taylor, W. H. (1955). Brit. J. Haemat., 1, 241. Allott, E. N. (1939). Lancet, 1, 1035. (1957). Ibid., 1, 246.

Anand, B. K., and Dua. S. (1956). Indian J. med. Res., 44, 121.

Anthonisen, P., Hilden, T., and Thomsen, A. C. (1954). Acta med. scand., 150, 355.

August, J. T., Nelson, D. H., and Thorn, G. W. (1958). J. clin. Invest., $37,1549$.

Black, D. A. K. (1952). Sodium Metabolism in Health and Disease. Blackwell, Oxford.

Borst, J. G. G. (1938). Acta med. scand., 97, 68.

- (1951). Lancet, 2, 887.

Brun, C. (1954). Acute Anuria. Munksgaard, Copenhagen.

Cooper, I. S., and Crevier, P. H. (1952). J. clin. Endocr., 12, 821.

- and MacCarty, C. S. (1951). Proc. Mayo Clin., 26, 354.

Cort, J. H. (1953). Nature (Lond.), 171, 784.

(1954). Lancet, 1, 752.

Cushny, A. R. (1926). The Secretion of the Urine. Longmans, Green, London.

Elliot, A. (1955). Acta med. scand., 150, 467. 
Engel, F. L., and Jaeger, C. (1954). Amer. J. Med., 17, 196.

Engstrom, W. W., and Liebman, A. (1953). Ibid., 15, 180.

Farrell, G. (1959). Endocrinology, 65, 29.

Földi, M., Korách, A. G. B., and Takács, L. (1955). Nature (Lond.), 176, 120.

Fourman, P., and Leeson, P. M. (1958). Ciba Foundation Colloquia on Ageing, Vol. 4, p. 36. Churchill, London.

Fullerton, H. W., Lyall, A., and Davidson, L. S. P. (1932). Lancet, 1, 558.

Goodale, W. T., and Kinney, T. D. (1949). Ann. intern. Med., 31, 1118.

Gordon, G. L., and Goldner, F. (1957). Amer. J. Med., 23, 543

Higgins, G., Lewin, W., O'Brien, J. R. P., and Taylor, W. H. (1951). Lancet, 1, 1295

,-- , and - (1954). Ibid., 1, 61.

Jungmann, P., and Meyer, E. (1913). Arch. exp. Path. Pharmacol., 73, 49.

Lewy, F. H., and Gassmann, F. K. (1935). Amer. J. Physiol., 112, 504.

Luetscher, J. A. Jr., and Blackman, S. S. Jr. (1943). Ann. intern. Med., $18,741$.

McCance, R. A., and Lawrence, R. D. (1935). Quart. J. Med., n.s. 4, 53.

_, Widdowson, E. M. (1939). J. Physiol. (Lond.), 95, 36.

Young, W. F., and Black, D. A. K. (1944). Ibid., 102, 415.

Maizels, M., and McArthur, C. B. (1930). Quart. J. Med., 23, 171.
Nadal, J. W., Pedersen, S., and Maddock, W. G. (1941). J. clin. Invest., 20, 691 .

Natelson, S., and Alexander, M. O. (1955). A.M.A. Arch. intern. Med., 96, 172.

Noble, R. L., Rinderknecht, H., and Williams, P. C. (1939). J. Physiol. (Lond.), 96, 293.

Persson, E. (1953). Nord. Med., 50, 1690

Peters, J. P. (1948). New Engl. J. Med., 239, 353.

Petit-Dutaillis, E., and Bernard-Weil, E. (1958). Métabolisme de l'eau dans les traumatismes du crâne. Masson, Paris.

Sartorius, O. W., and Burlington, H. (1956). Amer. J. Physiol., 185, 407.

Schoolman, H. M., Dubin, A., and Hoffman,W. S. (1955). A.M.A. Arch. intern. Med. 95, 15

Stein, M., Jinks, R., and Mirsky, J. A. (1952). Endocrinology, 51, 492.

Sweet, W. H., Cotzias, G. C., Seed, J., and Yakovlev, P. (1948). Ass. Res. nerv. Dis. Proc., 27, 795.

Taylor, W. H. (1951). Brit. med. J., 2, 1125.

(1954). Lancet, 1, 639.

(1957). Ibid., 2, 703.

- and Reid, J. V. O. (1958), Brit. J. Surg., 46, 136

Ullmann, T. D. (1953). Amer. J. Med., 15, 885.

Welt, L. G., Seldin, D. W., Nelson, W. P., German, W. J., and iN Peters, J. P. (1952), A.M.A. Arch intern. Med., 90, 355

Wise, B. L. (1956). Proc. Soc. exp. Biol. (N. Y.), 91, 557.

Wrong, O. (1957). Brit. med. Bull., 13, 10.

Zimmermann, B., and Freier, E. F. (1952). Surgery, 31, 373. 